\title{
The impact of different philosophical approaches towards the conservation of ancient monasteries in Cyprus
}

\author{
M. Philokyprou ${ }^{1} \&$ E. Petropoulou ${ }^{2}$ \\ ${ }^{1}$ Department of Architecture, University of Cyprus, Cyprus \\ ${ }^{2}$ Nicosia Municipality, Cyprus
}

\begin{abstract}
The international conventions and charters for conservation give general guidance for the rehabilitation of heritage buildings, but at the same time different philosophical approaches and strategies are involved. These approaches are related to the hierarchy of values for historic buildings as well as their new structural and functional requirements. This paper analyses the current trends in rehabilitation in Cyprus demonstrating different approaches, with an emphasis on the revival of ancient monasteries. Through the presentation of the conservation of two cases: the restoration of Panayia tou Sinti Monastery in Paphos and the revival of Ayios Nicolaos Monastery in Orounda, the positive and negative consequences of the different philosophies and strategies followed will be demonstrated. With the involvement of the authors, the monastery of Panayia tou Sinti was restored in the form of ruins, became an open-air museum and was awarded with a Europa Nostra prize. On the other hand, the monastery of Ayios Nicolaos has undergone a comprehensive maintenance and new extensions were designed by the authors and were erected using appropriate materials and forms for the enhancement of the new structures in the existing environment. Through these examples, different approaches for restoring historic buildings - "museum" conservation, final form of ruins, matters of authenticity, dynamic maintenance, compatibility of materials - are discussed. This paper analyses the procedures for investigating and assessing the values of historic buildings within the philosophical framework of international principles for rehabilitation prior to the adoption of the strategy to be followed.

Keywords: rehabilitation, ruins, monastery, reconstruction, reuse, authenticity, aesthetical values, abandonment, critical approach.
\end{abstract}




\section{Introduction}

Rehabilitation of archaeological sites, historic buildings as well as vernacular dwellings and settlements in Cyprus, follow the international conventions and charters for conservation in general, but at the same time different philosophical approaches and strategies are involved depending on the hierarchy of values for the different categories of building complexes. In the cases of high archaeological and historic values, the buildings remain in their existing form, usually conserved as ruins, avoiding any interventions that will endanger these values. On the other hand, in less important structures (regarding their historic value), special consideration is given for their functional and use values. These latter buildings are restored in their original form, with such interventions as are necessary to be adapted to contemporary needs.

The archaeological and historic values of building complexes are associated with their age, thus archaeological sites of ancient times (prehistoric - historic) or early Christian period (palaiochristian churches) are strictly conserved as found, avoiding any reconstruction due to the lack of sufficient evidence in accordance with article 9 of the Venice Charter stating that "restoration work must stop at the point where conjecture begins". On the other hand, many byzantine churches and monasteries (of medieval times) have usually undergone complete restoration based on strong evidence of their original form and due to the need for revival and reuse (Panayia tou Kykkou, Ayios Iraklidios, Ayios Minas etc).

The historic, architectural, social, environmental and aesthetic values of byzantine monasteries in Cyprus are very important. Every monastery is unique, being harmoniously integrated into the natural and built environment. Unfortunately, today there are many neglected monasteries on the island, endangered of becoming completely destroyed (Ayios Savvas tis Karonas, Panayia Agria, Panayia ton Elikon). In the last centuries and especially during Ottoman times and British rule, many monasteries were abandoned due to social and political reasons, and more specifically due to the high taxes and strict legislation. Natural causes also led to the gradual abandonment and destruction of many other monasteries. At the same time, valuable evidence, morphological forms and architectural elements were preserved intact due to neglect, therefore leaving abandoned sites as virgin ground for research and action towards successful restoration and rehabilitation.

\subsection{Dealing with monasteries as a living heritage}

When dealing with abandoned monasteries, there is often a dilemma: preserve them in their ruinous condition as found or restore them completely. The division of monuments into "dead" and "living" is not considered appropriate anymore, because every monument, in any condition, is a "living" example of civilization, capable of transmitting certain messages. "Museum" conservation and "passive" maintenance of existing building complexes are considered as the best option only in a few cases. In 1849, John Ruskin emphasised the authenticity of monuments in close relation to their age and refused any reconstruction, 
avoiding any falsification. Since then, the perception regarding authenticity has changed (Viollet-le-Duc, Boito etc.) and the "dynamic maintenance" approach is more often encouraged, based on the motivation of human resources. According to the contemporary accepted strategies, any intervention should aim to return monuments to society, as living complexes, creating new human environments. The reorganization of monastery communities and the dynamic integration of new functions will lead to the revival of old abandoned monasteries. The intention to restore a monument and bring it back to a new living function constitutes a socially-centred approach. According to the Declaration of Amsterdam, the success of any integrated conservation depends on the consideration of social factors.

\section{Case studies}

In this paper, two case studies are presented regarding the conservation of two historic monasteries (monastery of Ayios Nicoalaos in Orounda and monastery of Panayia tou Sint in Paphos), showing the positive and negative consequences of different philosophies and approaches followed in each monastery.

\subsection{The monastery of Ayios Nicolaos, in Orounda, Nicosia}

The old monastery of Ayios Nicolaos, situated on the west bank of the Serrachi River, is dated back to the early $16^{\text {th }}$ century and it has been declared an ancient monument. The church is a single-aisled domed building with a crude stone carving of the lion of St. Mark over its west entrance (Gunnis [1]). The monastery buildings are located around a central courtyard. The monastery was abandoned during the Ottoman times and reused in later times as a farmhouse (Goodwin [2]). In 1733, repairs are recorded but since then, the monastery was completely abandoned (fig.1). Small scale conservation works were carried out by the Department of Antiquities in 1977, and later in 1990, a restoration project was carried out in order to reuse the complex as a monastery.

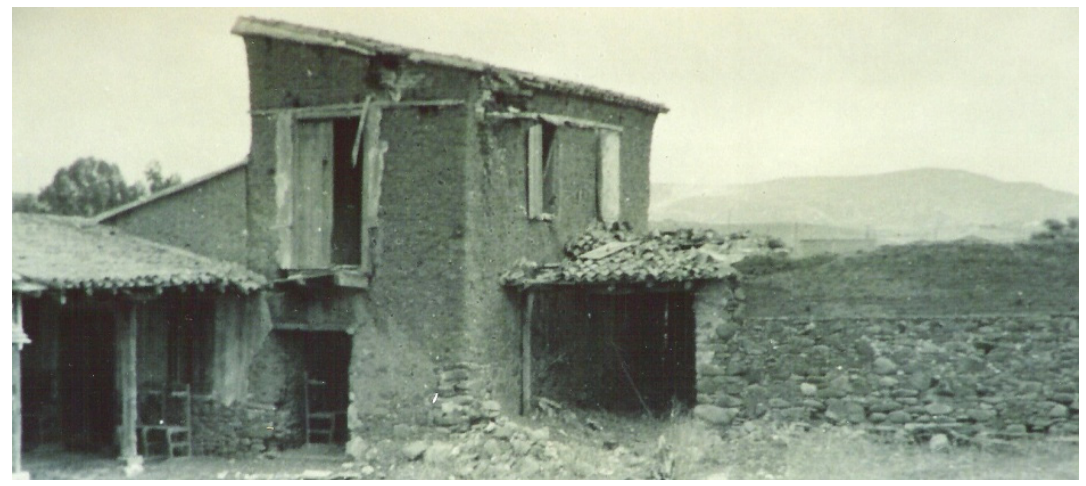

Figure 1: The ancient monastery of Ayios Nicolaos before conservation works. 
The restoration study was based on in situ evidence and historical information. The buildings of the monastery were restored to their original form and architectural character using traditional materials and building methods (fig. 2). The individual rooms were conserved and the complex was reused as a monastery. The complex was successfully rehabilitated by an active sisterhood, which gave life to the abandoned monastery. Soon the existing buildings proved to be too small and new additions were necessary, in order to fulfil the needs of the sisterhood (fig. 3).

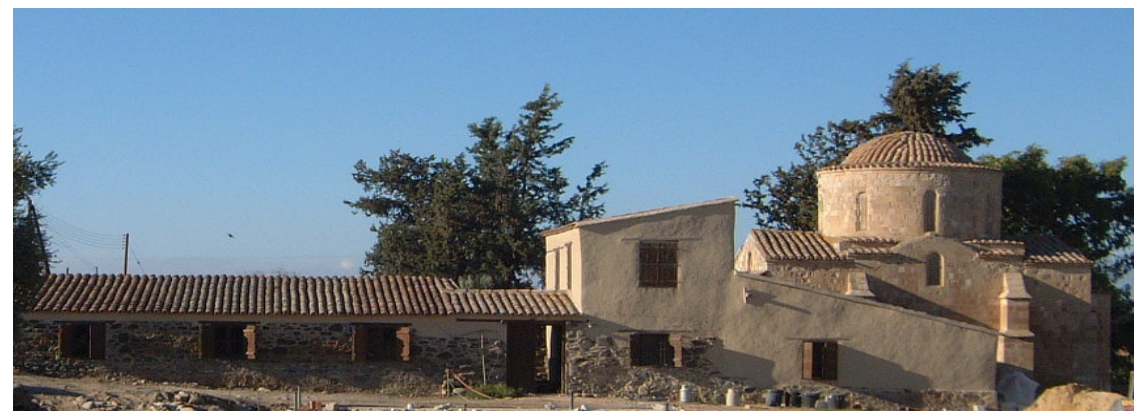

Figure 2: The historic monastery of Ayios Nicolaos after conservation works and before the erection of the extensions.

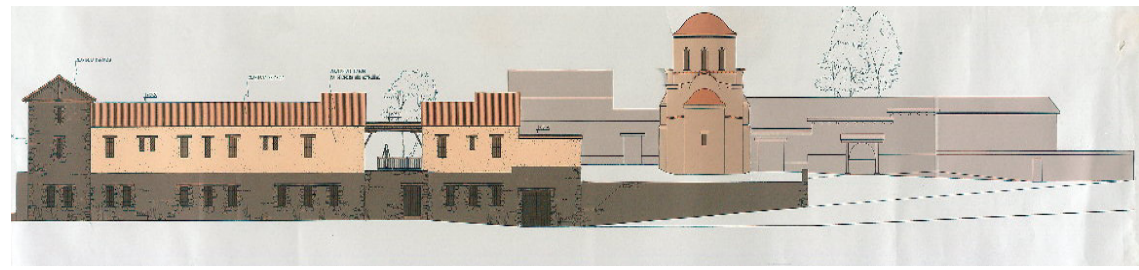

Figure 3: East elevation of the new complex erected attached to the historic monastery of Ayios Nicolaos.

In 1999, the extension of the monastery was decided by adding a new complex of buildings in direct relation to the historic monastery. The new complex was designed by two architects (E. Petropoulou and M. Philokyprou), who supervised the whole project.

The project was approached as an addition to the existing historic monastery, and at the same time as an independent section, including a second courtyard surrounded by the private premises of the sisterhood. These premises include dormitories, workshops for handicrafts and icons, a kitchen and a dining room, a library and a small chapel, as well as other auxiliary areas. The new structures are organised in three wings, situated to the east, west and south of the new courtyard, while the north side is defined by the old monastery. The rooms of each wing are developed in a line, according to the traditional monastery architecture, with long covered corridors acting as semi-open spaces. 
The design of the new complex was based on the internationally-accepted principles for the erection of new buildings in sensitive built environments (ICOMOS - Budapest 1972).

- The use of traditional materials and techniques was a precondition and has contributed, to the highest degree, to the embodiment of and respect for the existing historic monument.

- The design principles of the existing complex were successfully used for the design of the additions, such as the continuous façades built of stone and mud-bricks, the roofing materials, the proportions of spaces - width, height, and volumes.

- Contemporary techniques and materials were used where necessary, but in such a way that the unity of the complex was not disturbed and its historic, architectural and aesthetic values were not affected.

The complex was built with load-bearing walls, with a rubble stone base and a mud-brick superstructure. The mud-bricks were made on site by the villagers on a voluntary basis. The exterior façades of the stone walls remained uncovered, enhancing the prevalence of human scale, while gypsum plaster was introduced in the interior. The mud-brick superstructure was mud plastered on the outside. Simple structural solutions were designed for bridging small and large spans. Ceramic tiles covered the inclined roofs, while flat roofs were covered with special insulation materials and a final course in the colours of the surrounding environment.

The architectural forms, related to the materials and techniques used were successfully integrated into the existing complex, but at the same time revealed their contemporary character. The new section was built to the south of the existing monastery, aiming to be invisible when approaching the monastery from the nearby village of Orounda. The scale of the existing monastery as well as the simple and humble natural built environment in the vicinity were completely respected by using one and two-storey buildings with inclined and flat roofs defining the upper line of the elevations and creating unity in the whole design (fig. 4).

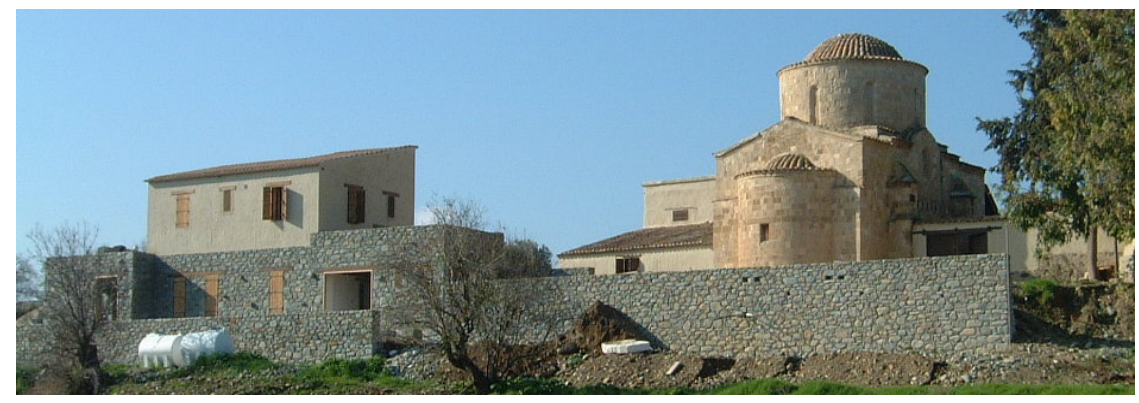

Figure 4: East elevation of the new additions of the monastery of Ayios Nicolaos. 


\subsection{The monastery of Panayia tou Sinti, Paphos}

The monastery of Panayia tou Sinti, in the Pahos district, is built in a valley on the western bank of the Xeropotamos River, at the point where it meets the Sinti River. Historic evidence about the monastery is scant. In a manuscript from the period of the Venetian occupation of the island (end of the 15th century), Sinti Monastery is mentioned among the villages of Paphos. References to it are found in Ottoman and Greek papers of the 16th, 17th and 18th centuries which were kept in the archives of Kykkos Monastery. In these papers, a terminus ante quem to the end of the 16th century is provided. Initially, Panayia tou Sinti was most probably an independent monastery. During the Ottoman period (1571-1878), the monastery became an annex of the powerful Kykkos Monastery. In the beginning of the 17th century, it was bought by a Turk, but later sold to a Christian. It was used as a monastery when the famous Russian traveller, Basil Barsky, visited it in 1735 (Stylianou [3]). At the time, the land in the vicinity and the two water mills belonged to the monastery. Sinti Monastery was visited by famous historian-travellers - Turner in 1815 (Cobham [4]), Jeffery in 1918 [5] and Gunnis in 1936 [1] - who give brief descriptions of the complex.

The monastery was in use until the early 20th century (1927). In the early fifties, its property was sold to the inhabitants of the nearby villages. Great damages took place as the villagers removed all salvageable material, corner stones, etc. It was thus abandoned in a terrible condition endangered to complete destruction. In September 1966, the Department of Antiquities declared the monastery as an Ancient Monument.

The monastery buildings are of stone, in one or two storeys, enclosing a central stone paved courtyard on three sides, with the church completing the enclosure on the south (fig. 5). The entrance to the complex was found to the east side, but the detailed documentation and research revealed the original covered entrance to the north.

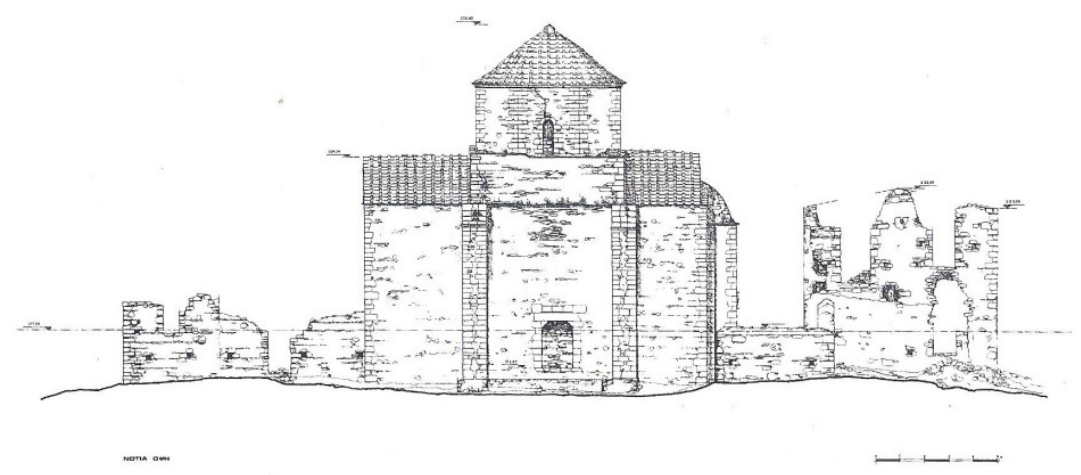

Figure 5: South elevation of the church and the monastery complex (survey drawing - N. Chrysochou, E. Kalliri, E. Petropoulou, M. Philokyprou, A. Psevdodiakos). 
The church is dedicated to the Virgin Mary. It is a Franco-byzantine singleaisled type of church with a dome and a double-slope roof. It embodies gothic elements such as the pointed vault and internal arches, an arched door pediment, rich door jamb mouldings and an oculus, dating the church prior to the monastery in the second half of the 16th century. When the buildings were erected, the south entrance of the church was closed, in order to enclose the church in the monastery complex.

Dating of the monastery buildings reveals different building phases. The north wing is older and contemporary with the church. The original entrance was blocked due to earth slippage before 1735 as Basil Barsky does not mention its existence (Stylianou [3]). After the blocking of this entrance, a staircase leading to the first storey was built in front of its opening. The rest of the rooms in the north wing (refectory, kitchen) were erected later after the building of the north entrance, as the existence of older foundations reveals. The east wing was probably built in different phases with two central rooms built firstly and the corner rooms added later. These rooms were the monks' dormitories. The west wing was probably built at a later stage when there was a need for more storage space, stables etc. The east entrance, with a low rounded arch is dated to the 20th century.

The monastery complex is considered as a very important monument with great archaeological, historic, aesthetic and architectural values. The church is an outstanding example of 16th century religious architecture with its unique typology and the remarkable combination of byzantine and gothic elements. The monastery buildings preserve many of the characteristics of their original design, typical of the monastery architecture of Cyprus (the main covered entrance, refectory with pointed arch, stone-built fireplaces, etc.). The harmonious coexistence of the monastery buildings in terms of materials, colours and proportions with the local environment is of significant importance. It is beautifully integrated into the natural landscape and constitutes a magnificent landscape monument.

The condition of the church was rather good compared to the rest of the buildings. Its north and south walls, as well as its double slope roof with byzantine-type tiles, were almost intact. However, the east and west walls and the dome had serious and widely-spread structural cracks caused mainly by earthquakes. The main damages to the monastery buildings are the demolition of great parts of the walls and arches, the removal of all the plasters and the weathering of individual stones. These damages were due to the abandonment of the monastery during recent years, the destructive earthquake of 1953, and the removal of the wooden elements (roof beams, lintels, etc.) as well as corner stones, which exposed the interior to the destructive weather elements. Wild vegetation grown within the mass of the walls caused severe damages as well.

The study, which included a detailed documentation of the monument as well as conservation proposals, was undertaken by a group of five architects (N. Chrysochou, E. Kalliri, E. Petropoulou, M. Philokyprou, A. Pseftodiakos) under the supervision of the Museum of Kykkos Monastery in collaboration with the Department of Antiquities. Conservation works began in June 1994. 
The approach of the study was to preserve the ruins and to restore those parts of the monastery which conserved evidence of their original character and form (figs. 6(a) and (b)). Any hypothesis would endanger the integrity of the monument which was one of the very few in the island that had not undergone any modern intervention and alteration of character. In the framework of this approach, the main purpose of the project was clearly the consolidation and protection of the monument from decay and deterioration with minimum interventions. In addition, every effort was made to preserve old textures and surfaces. The cracks and lacunae of the walls were filled in. Missing quoins and wooden lintels were replaced, and the rubble masonry over the lintels was rebuilt for structural reasons. Traditional construction methods with local stone and lime mortar were used. Modern materials were restricted to a minimum.

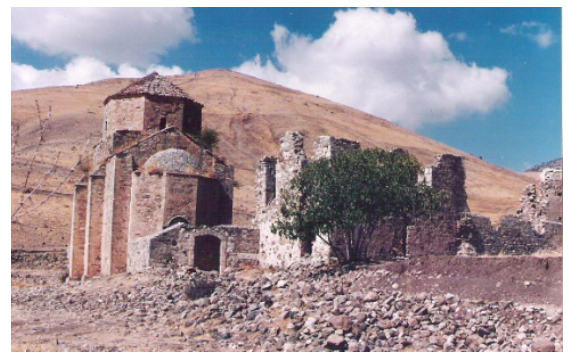

(a)

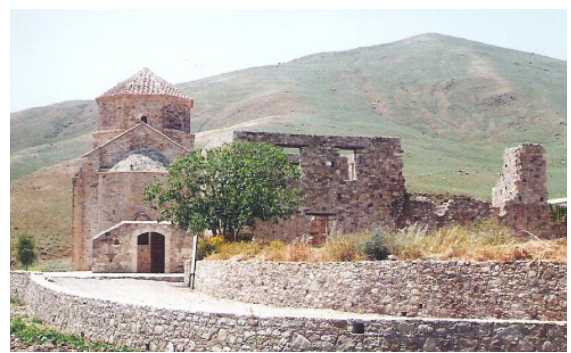

(b)

Figure 6: The monastery of Panayia tou Sinti from the east before (a), and after (b) conservation works.

Rebuilt areas and elements were defined by small pieces of brick or tile set in the mortar joints. This follows article 9 of the Venice Charter which states that "any extra work which is indispensable must be distinct from the architectural composition and must bear a contemporary stamp". According to Camille Boito "caution is recommended in reconstruction". He agreed to accept reconstructions exceptionally when there was clear evidence to justify them. "All new elements should be marked and dated in order to be recognizable and subject to criticism by scholars".

Initially, the east and west walls of the church were conserved by filling the cracks using traditional methods. The dome was repaired by replacing the missing keystones of its four windows. The stones blocking these windows and the west oculus were removed and clear glass panels were fitted. The original byzantine roof tiles were removed; the roof was waterproofed and tiles were reused. It was decided that the blocked south door of the church should remain closed since the blockage took place when the monastery was erected in its present form, and thus constitutes part of the history of the monument. Therefore, the monument was not conserved in its original form, but later phases were respected as part of the monument's history. This follows Article 11 of the Venice Charter referring that "The valid contributions of all periods to the building of a monument must be respected, since unity of style is not the aim of a 
restoration". At the north entrance of the church, the semi-circular steps were reconstructed on the revealed foundations.

The walls of the north wing of the monastery were presented at their full height. Thus it was decided to restore the former refectory and the two adjacent rooms of this wing. The original gothic pointed arch that internally subdivided the refectory and its roof were reconstructed (fig. 7). The refectory is now used as a small museum where objects related to the history of the monastery are exhibited. As the bases of three pointed arches were revealed during conservation works, and with the aid of old photographs, the original arcade in front of the north wing was reconstructed. The original north entrance of the monastery, which had been blocked, was restored to its original form by demolishing the later additions (fig. 7), following article 11 of the Venice Charter which stated "When a building includes the superimposed work of different periods, revealing of the underlying state can only be justified in exceptional circumstances and when what is removed is of little interest and the material which is brought to light is of great historical, archaeological or aesthetic value, and its state of preservation good enough to justify the action".

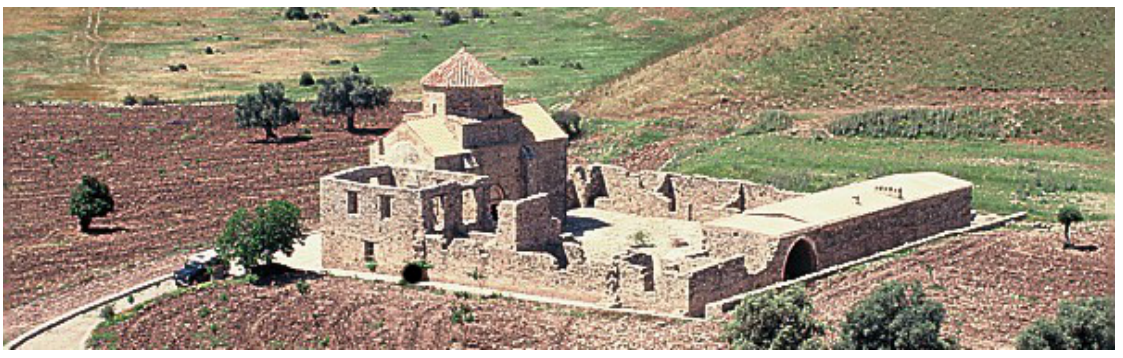

Figure 7: General view of the monastery of Panayia tou Sinti after conservation works.

The east wing of the monastery, which has a second storey in its southern part, has not been fully restored. The walls and the exterior buttresses were repaired. The interior arch of the central room of this wing was restored to its original form for structural and aesthetic reasons. The ruined west wing was merely repaired using the fallen stones and was conserved in its ruinous condition.

The conservation works were completed in May 1997. The church is being reused as a place of worship while the whole complex preserves its sacred character and is available for pilgrims as well as visitors. The entire monastery comprises an archaeological site as well as an individual outdoor museum. This approach and restoration proposal is the first to be implemented in Cyprus for a large historic complex.

\section{Discussion and conclusions}

The final decision for the restoration approach for a historic and archaeological site of great importance, such as a medieval monastery complex, should be based 
on the evaluation, assessment and hierarchy of its different values. In the case of Panayia tou Sinti, the archaeological and historic values were considered of greater importance than its social and use values as a living heritage. In addition, there was no need for the rehabilitation and reuse of the monastery by the owner. Therefore, the decision for its preservation was directed towards the conservation of the monastery following a "museum" approach, in order to promote the monastery as a religious symbol and as a site for pilgrims and not as a living place. Thus, it remained in a ruined condition, revealing its authentic and picturesque elements. Today, a large number of tourists visit the monastery travelling on donkeys from nearby villages. It is noteworthy that even in the conservation of ruins some authentic elements are lost. According to John Ruskin, every conservation work leads to the destruction of some authentic evidence.

The conservation of a place in a ruined condition can be related to the theories of keeping the old structures "open" for interpretation (Otero-Palios [6, 7]). Otero Palios [6] argues that "the unfinished parts of a monument give a metaphor to consider the level of completion". Brandi [8] also refers to the impact of lacunae, arguing that "the recovery of all moments of the past of a monument is impossible. Instead, only by recognizing the lacunae in our picture of the past, can we consider the remaining record of time as history". Preservation offers a critical historical view of an object in space and time, but only by full recognition of the absences in both physical and temporal records (Ciccone [9]).

The critical question in every conservation work is whether a condition of wholeness or completeness is an absolute requirement of architecture (Matero [10]). Indeed, most of the restoration debates of the late nineteenth century in Europe revolved around the decisions to complete or "correct" individual monuments, thereby establishing their architectural and stylistic unity. Twenty years ago Paul Philippot stated: "What is to be considered the whole of the object? What has been the history of the object? These questions are necessary in consideration of what constitutes wholeness, integrity, value, significance, and meaning for any given work and the assumed compromises which result from alteration, degradation, and loss, and the arguments for compensation" (Matero [10]). It is in the context of such debates that Brandi's theory of restoration [8] attempted to establish an approach that recognized and qualified the aesthetic, historic and functional values of heritage.

In the case of the monastery of Ayios Nicolaos in Orounda, its social value and the need for its reuse was considered of utmost importance compared to its archaeological and historic values. The monastery is being reused, thereby maintaining its social revival and regaining its old character. Therefore, it was restored in order to serve the needs of its new occupants. The importance of ancient monasteries is associated with their continuous use and reuse. The complete restoration of the monastery buildings of Ayios Nicolaos and the installation of contemporary facilities as well as the erection of large-scale extensions led to some alterations of the authentic image of the monastery. Yet the interventions are well-recognized and the careful eye of the observer can restore the original image of the historical part. 
To preserve ancient monasteries means to protect a sense of identity, to take care of the physical form and fabric and to respect the ways in which they were used and understood. According to the Charter of Athens, the occupancy of the buildings which ensures the continuity of their life should be maintained and the buildings should be used for a purpose which respects their historic and artistic character.

Comparing the two cases analysed above, it is obvious that in the Sinti Monastery, the restoration approach was focused on its aesthetic and historic values, whereas in the case of Ayios Nicolaos, functional objectives dominated and the aesthetic and historic values were secondary. It is noteworthy that architectural work is not exclusively aesthetically or functionally experienced but demands to be experienced in both ways.

The visual appearance of any small or large-scale interventions is very important, affecting the aesthetic value of each monument. These interventions should be clearly identified from, but at the same time embodied and incorporated into, the original fabric in order to maintain the unity of the existing structure. Reversibility and re-treatability is essential for any intervention to historic structures, thus preserving the integrity of the original text and the possibilities for alternative interpretations in the future (Matero [10]).

During conservation work, a great importance is given to the authenticity of the existing structures. According to John Ruskin, "restoration is a lie from the beginning to the end", thus defining authentic character only by age. In contrast, Viollet-le-Duc defined authenticity not by age, but according to three criteria: image (style), form (structure) and material. A new definition of authenticity derives from the theories of Brandi [8], considering that cultural works have a continuing history. Their present state records not only the moment of creation, but also a whole subsequent sequence of events (damaged and repaired, cleaned and restored and sometimes destroyed) (Matero [10]).

Before final decisions are made for any intervention in a historic monastery complex, investigation and evaluation of positive and negative parameters should necessarily be undertaken in order to avoid (as much as possible) the negative consequences of the intervention. The role of a critical conservation approach in relation to the history of a monument is of utmost importance. Historic time in relation to any historic building is seen by Brandi [8] in three district aspects: the period of creation, the time from the end of the first period till the present and the actual moment of perception of the work of art in our consciousness. According to him, the only legitimate moment for restoration is the present [8]. This critical attitude towards conservation is also expressed by Jokilehto [11] who states that "even though the principles indicated in restoration charters can be kept in mind as a general guidance, the process must necessarily be based on critical judgment". Therefore, restoration must take into account the historic context where the heritage was created and with which it associates.

For the rehabilitation of old monasteries, contemporary and traditional methods can be followed. The aim is to respect the existing fabric, preserve all authentic materials that are in good condition and conserve the structures using compatible materials and techniques. In the design interventions, special care 
should be given to the relations between the new and the old, and also awareness should be developed concerning the different concepts and ideas that support the architectural choices. The design interventions incorporated should be developed through a holistic approach, taking into serious consideration the different values of the buildings. To achieve this, the co-existence of the rehabilitation process with the concept of preservation is essential, following a critical conservation attitude.

\section{References}

[1] Gunnis, R., Historic Cyprus, Nicosia, 1936, 1973.

[2] Goodwin, J.C., A Historical Toponymy of Cyprus, Nicosia, 1978

[3] Stylianou, A., 'Travels of Barsky in Cyprus' Kypriakai Spoudai 21, pp. 77 8, 1957.

[4] Cobham, C.D., Exceptra Cypria. Materials for a History of Cyprus. Cambridge, 1908.

[5] Jeffery J., Historic Monuments of Cyprus, Nicosia, 1918.

[6] Otero-Pailos, J. The Contemporary Stamp of Incompleteness, Future Anterior, 1(2), pp. iii-viii, 2004.

[7] Otero-Pailos, J., 'Historic Provocation: Thinking Past Architecture and Preservation', Future Anterior, 2(2), pp. iii-vi, 2005.

[8] Brandi, C., Theory of Restoration, Rome, Giuseppe Basile, 2005.

[9] Ciccone, P., Space, Time and Preservation, Future Anterior, 4(1), pp. ix-xi, 2007.

[10] Matero, F.G., 'Loss, Compensation and Authenticity: The contribution of Cesare Brandi to Architectural Conservation in America', Future Anterior 4 (1), pp. 45-55, 2007.

[11] Jokilehto, J., Preservation Theory Unfolding, Future Anterior, III(1), pp. 19, 2006. 